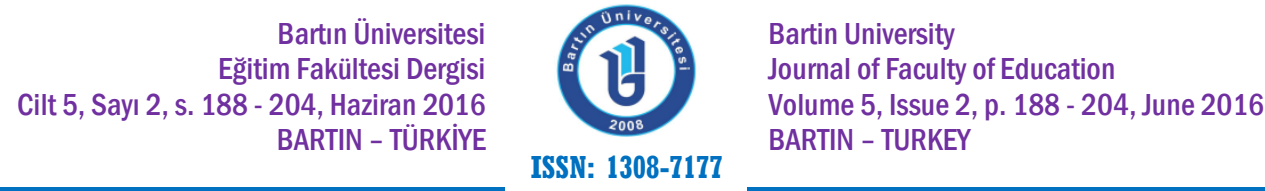

Doi: 10.14686/buefad.v5i2.5000184583

\title{
Eğitimde Sorgulamanın Gücü
}

Firdevs GÜNEŞ, Prof. Dr., Bartın Üniversitesi Eğitim Fakültesi, firdevsgunes@bartin.edu.tr

Öz: Sorgulama, öğrencilerin dil, zihinsel ve sosyal becerilerini geliştirmek amacıyla yürütülen etkinliklerin başında gelmektedir. Sorgulama ile düşünme, anlama, öğrenme, değerlendirme gibi süreçler daha kolay yürütülmektedir. Sokrates döneminden bu yana uzun bir geçmişe sahip olan sorgulamanın $2000^{\prime} l i$ yıllarda yeni eğitim yaklaşımları ile birlikte tekrar ön plana çıktı̆̆ı görülmektedir. Etkili ve güçlü bir eğitim etkinliği olan sorgulamanın temeli nitelikli sorulara dayanmaktadır. Öğrencilerin sorgulama becerilerini geliştirmek için sürekli sorular sorulmaktadır. Bu süreçte soruların amacı ve türlerine de dikkat edilmektedir. Açık uçlu sorular daha ayrıntılı cevapları ve eleştirel düşünmeyi getirmekte ve başka konuları araştırmaya teşvik etmektedir. Sorgulamada " kim, ne, nerede, niçin, nasıl, ne zaman" gibi başlayan sorulardan da yararlanılmaktadır. Öğrencilerin sorulara verdikleri cevaplar düzeltilerek öğrenme durumları izlenmektedir. Sorgulama etkinlikleri öğrencilerde aktif öğrenme, öğrenmeyi öğrenme, tartışma, sorun çözme, eleştirel düşünme gibi becerileri üst düzeyde geliştirmeye katkı sağlamaktadır. Ülkemizde 2005 illköğretim programlarıyla birlikte çocuk ve gençlerin eğitiminde sorgulama yöntem ve tekniklerine geniş yer verilmiştir. Programda öngörülen amaçlara ulaşmak için öğretmenlerin sorgulamayı önemsemesi, uygulaması, ülkemizin geleceğine yön verecek bireylerin yetişmesi beklenmektedir.

Anahtar Kelimeler: sorgulama, eğitim, öğrenme, öğretmen.

\section{The Power of Inquiry in Education}

Abstract: Inquiry takes the initial role in the activities performed based on the aims of developing the students' language, mental and social skills; raising their levels of thinking, understanding and learning; and facilitating the process of evaluation. The history of inquiry activities started at Socrates period and it has been observed that they have become prominent in 2000's with the new educational approaches. The inquiry which is the effective and powerful educational activity encourages the students' learning, thinking and taking responsibility skills. The operation of inquiry is based on effective and qualified questions. The good questions appropriate for the content should be prepared and the aim, quality and types of them should be paid attention on. Open-ended questions necessitate more detailed answers and critical thinking. These questions guide the discussion and encourage the examination of other topics. The questions beginning with the words of "who, what, where, why, how, when" should also be benefited from in the inquiry. The learning of the students should be examined by revising the answers of them to the questions. The inquiry activities should be cared in order to improve high level of thinking skills such as active learning, learning to learn, discussing and critical thinking. In our country, it is observed that the techniques and methods of inquiry have been widely used in 2005 middle school education programs. Our hopes are that the teachers take care of inquiry activities and reflect their applications so that the individuals directing our future, understanding and questioning are educated.

Key Words: inquiry, education, learning, teacher. 


\section{GíRiş}

Günümüz dünyası bir taraftan önemli bilimsel gelişmelere sahne olmakta bir taraftan da ciddî sorunlarla yüz yüze bulunmaktadır. Bunların önümüzdeki yıllarda giderek artacağı ve daha da karmaşıklaşacağı bilinmektedir. Böyle bir dünyada yaşamak ve gelişmelere uyum sağlamak için bireylerin kendilerine aktarılan bilgileri iyi düşünmeleri ve sorgulamaları gerekmektedir. Bu durum eğitim alanında sorgulamaya ağırlık veren yaklaşım ve modelleri gündeme getirmektedir. Bunlar yapılandırıcı yaklaşım, sorgulama temelli öğrenme gibi sıralanmaktadır. Eğitim sürecinde ise bilgi aktarma yerine düşünme, anlama, sorgulama, sorun çözme gibi becerileri geliştirmeye ve yaşam boyu öğrenmeye ağırlık verilmektedir. Böylece bireylerde çok yönlü düşünme, sorgulama gibi becerileri geliştirme önem kazanmaktadır.

Son yıllarda "Geleceğin bireylerini yetiştirmek için hangi beceriler öğretilmeli? Bu beceriler nasıl seçilmeli?" gibi sorulardan hareketle bir dizi araştırma yapılmaktadır. Bu çalışmalar OCDE tarafından da desteklemekte, geleceğin bireylerini yetiştirmek için anahtar beceriler belirlenmektedir. Bu konuda çeşitli ülkelerin uzmanlarıyla yapılan uzun süreli çalışmalar sonunda disiplinler arası bir yaklaşımla, bazı anahtar beceriler belirlenmiştir. Bunlar zihinsel, bireysel, sosyal ve zihinsel bağımsızlık becerileri olarak sıralanmıştır. Anahtar becerilerin merkezine zihinsel beceriler yerleştirilmiş ve bunların zorunlu olduğu vurgulanmıştır. Zihinsel becerilerin kalbi "düşünme ve sorgulama" olarak açıklanmıştır. Düşünme ve sorgulama bireyin karmaşık zihinsel süreçlerini etkilemekte, harekete geçirmekte, üst düzey öğrenme ve anlama becerilerini geliştirmektedir. Bir başka ifadeyle düşünme, sorgulama, anlama, zihnini yönetme gibi beceriler bilginin zihinde üst düzeyde yapılandırılmasını sağlamaktadır (OCDE, 2005). Bu nedenle sorgulama bütün zihinsel işlem ve süreçlerinin merkezine yerleştirilmiştir.

Sorgulamak evde ailede ve işyerinde yapılan günlük bir eylemdir. Çocuklar sorgulayarak büyürler. Çevresinde gördüklerini anlamak ve öğrenmek için sürekli sorular sorarlar. Soru sorma işlemi bazı dönemlerde yoğun olmakla birlikte çocuğun gelişimi boyunca devam etmektedir. Sorgulama doğuştan gelen bir beceri değildir. Bu beceriyi geliştirmek için etkili bir eğitime intiyaç duyulmaktadır. Ancak çoğu kişi bu konuda bir eğitim almadığından nasıl sorgulama yapılacağını bilmemektedir. Bu nedenle gelişmiş ülkelerde bireysel gelişimin önemli bir boyutu olarak ele alınan sorgulamaya eğitim faaliyetleri içerisinde geniş yer verilmektedir. Öğrencilere çeşitli etkinliklerle sorgulama teknikleri uygulamalı olarak öğretilmektedir.

Sorgulama bireyin zihin yapısında önemli değişme ve gelişmelere neden olmaktadır. Bu durum dil, zihinsel, sosyal gibi becerilerin yanında bireyin diğer yeteneklerini de etkilemekte ve geliştirmektedir. Çünkü birey sorgulayarak edindiği bilgi ve becerileri, günlük yaşamına aktarmakta, uygulamakta ve her alandaki becerilerini geliştirmektedir. Bu nedenle öğrenme alışkanlıklarının kazanıldığı ve kalıcı hale geldiği ilkokul yıllarında sorgulama eğitimine başlanmakta, aşamalı olarak düzeylere ve alanlara göre genişletilmektedir. Çocukların erken yaşlardan itibaren sorgulama becerilerini kazanmaları ve öğrenmekten zevk almaları için uygun ortamlar hazırlanmaktadır. Bu süreçte sorgulamanın dışarıdan içeriye, çevreden kendine doğru ilerlemesi ve kendini sorgulamasına da dikkat edilmektedir.

\subsection{Sorgulama Nedir?}

'Sorgulama' çok eski yıllara uzanan ve Sokrates'ten bu yana eğitim alanında kullanılan bir kavramdır. Yabancı sözlüklerde sorgulama, "bir sorun hakkında çeşitli sorular sormak, sorun olan bir durumla ilgili yorumlar yapmak" olarak verilmektedir. TDK Türkçe Sözlükte "Suç niteliğinde bulunan bir sorun üzerine ilgili bulunanlara sorular sormak", denilerek sınırlı bir açıklama yapılmaktadır. Yöntembilim Terimleri Sözlüğünde (1981) "Bir konuyu sorular sorup yanıtlar vererek araştırma" olarak açıklanmaktadır. Bazı kaynaklarda sorgulama "Konu, kişi, 
varlık, olgu, fikir, inanç, ideoloji gibi hususlar hakkında sorular sorma, düşünme, araştırma ve inceleme yaparak bunların doğru ve yanlış yönlerini ortaya koyma" olarak verilmektedir. Felsefe alanında sorgulama "bir konuda kusursuz düşünceyi ortaya çıkarmak için sistemli ve özdenetimli sorular sorma işlemi olarak" tanımlanmaktadır. Eğitim alanında sorgulama "çeşitli sorularla öğrencilerin dil ve zihin becerilerini geliştirerek düşünme, anlama ve öğrenme düzeyini yükseltme" anlamında ele alınmaktadır.

Görüldüğü gibi sorgulama hukuk, yöntembilim, felsefe, eğitim vb. alanlarda farklı anlamda ele alınmaktadır. Sorgulama ile ilgili tanım ve açıklamalar da alanlara göre değişmektedir. Ancak bütün tanım ve açıklamalarda ortak nokta "soru sorma, sorularla araştırma, düşünme ve öğrenmeyi geliştirme" olmaktadır. Buradan hareketle eğitimde sorgulama "sistemli sorularla öğrencilerin sorgulama becerilerini geliştirme ve böylece düşünme, anlama ve öğrenme düzeylerini yükseltme" olarak tanımlanmaktadır.

Sorgulama, bir dizi soruyla olguların neden-sonuç ilişkilerini araştırma, analiz etme, düşünce üretme, düşünceleri düzenleme, görüşleri savunma, karşılaştırmalar yapma, çıkarımlarda bulunma, tartışmaları değerlendirme ve problem çözme işlemidir. Sorgulama aynı zamanda bilgi edinme, açıklama ve kavramlar arasındaki ilişkileri yapılandırma biçimidir. Sorgulama bazen problem çözme, karar verme, akıl yürütme, ilişki kurma, yaratıcı düşünme gibi kavramlarla aynı anlamda kullanılmaktadır. Ancak sorgulama bu kavramlardan farklıdır. Sorgulamada önce sorular sorulmakta, ardından tartışma yapılmakta ve sonunda yeni düşüncelere ulaşıımaktadır.

Sorgulama bazı kaynaklarda sanat, bazılarında yöntem ve teknik, bazılarında öğrenme aracı ve etkinlik, bazılarında ise yaklaşım, strateji ve beceri olarak karşımıza çıkmaktadır. Bu farkııık sorgulamanın kullanılma amacı ve uygulandığı alanlarla ilgili olmaktadır. Sorgulama felsefe alanında sanat olarak görülmekte, hukukta yöntem olarak uygulanmaktadır. Çeşitli disiplinlerde yöntem ve teknik, eğitim alanında yöntem, teknik, öğrenme aracı ve etkinlik olarak kullanılmaktadır. Yeni eğitim yaklaşımlarında ise öğrencilerde geliştirilecek bir beceri alanı olmaktadır.

\subsection{Eğitimde Sorgulama}

Sorgulama, antik dönemde Yunan filozofu Sokrates'in felsefî düşünme ve bilgiyi öğretme yönteminden gelmektedir. Sokratik yöntem olarak da bilinen bu yöntem günümüzde aktif öğretim yöntemi olarak kullanılmaktadır. Sokratik yöntem üç aşamalı olarak gerçekleştirilmektedir. illk aşamada bir konuda karşıdaki kişiye çeşitli sorular sorularak onun neyi bilip neyi bilmediği araştırılmaktadır. İkinci aşamada kişinin bilmediği husus ve konular hissettirilmektedir. Üçüncü aşamada ise sorgulanan konu hakkında fikir üretilmeye başlanmaktadır. Önce soru cevap yöntemi ile başlayan bu süreçte çeşitli konular tartışılmakta ve sonunda yeni fikirlere ulaşılmaya çalışılmaktadır. Kişi bildiği ve sorulan sorulara verdiği cevaplardan çıkarımlar yapmakta ve yaptığı çıkarımlar sayesinde karşısındakinin bilgilerine ulaşmaktadır. Günümüzde bu yöntem 'buldurma yöntemi' olarak uygulanmaktadır.

Sorgulama günümüzde bütün eğitim etkinliklerinin merkezinde yer almakta ve çoğu okulda yaygın olarak kullanılmaktadır. Araştırmalar $A B D^{\prime}$ de ortaokul öğretmenlerinin bir günde 395 soru sorduklarını ve öğrencilerin \% 80'inin bu soruları cevapladıklarını, Fransa'da ise ortaöğretim düzeyindeki 115 dersin $87^{\prime}$ sinde sorgulama yönteminin kullanıldığını ortaya çıkarmaktadır (Maulini, 2005, s.36). Bir başka araştırmada ise öğretmenlik deneyimi 5-10 yıl arasında olan öğretmenlerin günde ortalama 250-500 arası soru sordukları görülmektedir (Wragg ve Brown, 2001). Bu sonuçlar gelişmiş ülkelerde sorgulama yönteminin yaygın kullanıldığını ve öğretmen yetiştirme sürecinde sorgulama yöntemine ağıllık verildiğini 
göstermektedir. Yine araştırmalara göre sınıfta sorulan soruların çoğunluğu öğretmen tarafından hazırlanmaktadır (Maulini, 2005, Rieunier,2000).

Eğitimde sorgulamanın amacı öğrencileri öğrenmeye güdüleme, dil, zihinsel ve sosyal becerilerini geliştirme, düşünme, anlama ve öğrenme düzeyini yükseltme, eğitim öğretim ve değerlendirme sürecini kolaylaştırma olmaktadır. Bu amaçlarla yapılan sorgulama etkili ve güçlü bir eğitim etkinliği olarak karşımıza çıkmaktadır. Özellikle açık uçlu soruların sorulması eğitim programının amaç, hedef ve öğrenme sonuçlarını doğrudan etkilemektedir. Öğrencilerde merak uyandırma, eleştirel ve yansıtıcı düşünmeyi geliştirme, öğrendiklerini uygulamaya aktarmada sorgulama etkinliklerinin büyük payı bulunmaktadır. Sorgulama sırasında verilen cevaplar öğrencilerin bilgi düzeyleri, ne bilip bilmedikleri hakkında fikir vermekte ve eğitimin aşamalarını planlamayı kolaylaştırmaktadır. Öğrencilerin sorgulama becerilerini geliştirmek için önce anlama becerilerini geliştirmek, ardından içerikle ilgili bilgileri öğrenmelerini ve bunları uygulamaya aktarmalarını sağlamak gerekmektedir. Öğrencilerin kavramları derinlemesine anlamaları ve öğrenmeleri sorgulama işleminin başarılı olduğunun bir kanıtı olmaktadır (Ontario, 2011, s.1).

Eğitimde sorgulama iletişimsel ve etkileşimsel olmak üzere iki sürece dayanmaktadır. iletişimsel yönü 'verici', 'alıcı', 'ileti' ve 'dönüt' olmak üzere iletişim sürecinde kullanılan dört öge ile açıklanmakta, bu ögelerle hem iletişim kurulmakta hem de sorgulama yapılmaktadır. Bu durum aile, okul ve işyerlerinde açıkça görülmektedir. Etkileşimsel yönü ise öğretmen-öğrenci, yönetici-çalışan, soru soran-cevap veren, sorular ve ortam gibi değişkenler arasındaki etkileşimle gerçekleşmektedir. Maulini'ye (2005) göre soru sormak öğrencilerle etkileşime girmek demektir. Bu etkileşimin amacı öğrencilerin öğrenmelerini sağlamaktır. Sorgulama sırasında öğrenciler birbirlerine soru sorabilirler. Ancak sorgulama denilince genellikle öğretmenin soru sorduğu öğrencilerin de cevap verdiği etkinlik anlaşılmaktadır. Bu durum döneme, kültürlere ve kurumlara göre değişmektedir. Bazı kültürlerde öğrencilerin öğretmene ve arkadaşlarına soru sormaları istenmektedir (Maulini, 2005).

Eğitimde sorgulama bir güçtür. Bu güce ulaşmak için öğrencilere sorulacak sorular iyi hazırlanmalı veya seçilmelidir. Nitelikli sorular öğrencilerin eğitim, değişim ve gelişim yolculuğunda çok önemli olmaktadır. Özellikle düşünme, anlama ve öğrenmeye yönelik sorular öğrencilerin zihin yapısını geliştirmekte, üreticiliğe ve yaratıcılığa götürmektedir. Marilee Adams, "Yaşamınızı değiştirmek için sorularınızı değiştirin." demektedir. İnsanlığı, uygarlığı geliştiren, değiştiren kişiler genel olarak "etkili, farklı ve cesur sorular" sorarak yeni ürünler keşfeden kişilerdir. Sorgulama bireyleri bilgeliğe ve liderliğe götürmektedir. Bu nedenle eğitim sürecinde etkili sorularla öğrencilerin düşünme, anlama, öğrenme ve sorgulama becerileri geliştirilmeli, giderek kendilerini sorgulamaları ve sürekli geliştirmeleri hedeflenmelidir. Böylece gelecek nesilleri iyi yetiştirmek için sorgulamanın gücünden yararlanılmalıdır.

\subsection{Sorgulama Tür ve Düzeyleri}

Sorgulama bütün disiplinlerde eğitim etkinliklerinin kalbini oluşturmaktadır. Bu durum çocukluktan beri hepimizin hafızasındaki canlı okul hatıralarından biridir. Çoğumuzun sınıfın önünde öğretmen tarafından sorulan sorulara cevap vermeye çalışması aklından çıkmaz. Eğitim sürecinde yapılan bu sorgulamaların türleri ve kullanılan sorular birbirinden farklı olmaktadır. Örneğin öğrenmek için sorgulama ile değerlendirmek için yapılan sorgulama birbirinden farklıdır. Değerlendirme amaçlı sorgulama öğrencinin öğrenip öğrenmediğini kontrol etmeyi içermekle birlikte ikisinin mantığı farklıdır. Değerlendirme sorgulaması öğrencinin cevaplarının doğru olup olmadığına odaklanır. Bu sorulara göre öğrencilerin öğrenip öğrenmediğine karar verilir. Öğrenme sorgulaması ise öğrencileri bilgilendirmeye, dikkatini çekmeye, düşündürmeye ve farklı düzeydeki zihinsel becerileri geliştirmeye odaklanır (Astolfi, 2008, s.70). 
Düzeylere gelince, eğitimde sorgulama üç düzeyde ele alınmaktadır. Bunlar sorgulama, oto sorgulama ve meta sorgulama düzeyleri olmaktadır. İlk düzey temel sorgulamayı kapsamaktadır. Sorgulama, öğrencilerin öğrenme ve anlama düzeylerini geliştirmek için bilgi, beceri, teknik, tutum gibi hususlara yönelik soruları içermektedir (Bellenger ve Philippe,1996).

Oto sorgulama, öğrencilerin dinleyerek veya okuyarak aldıkları bilgileri bilinçli olarak incelemeleri, kendi kendilerine sorgulamaları, giderek sorgulama becerilerini geliştirmeleri, kendi öğrenmelerini planlama, kontrol etme ve yönlendirmelerini içermektedir. Bu süreçte bilgileri anlayıp anlamadıklarını sorgulama, dikkat, öğrenme gibi becerileri geliştirme de önemli olmaktadır (Viola, 2000). Bu sorgulamanın ikinci düzeyi olmakta, burada sorgulama işlemi bireye yönelmekte ve birey kendini sorgulamaya başlamaktadır.

Meta sorgulama ise öğrencilerin üst düzey anlama ve öğrenmelerini sağlamak için öğrenme, anlama ve düşünme süreçlerini sorgulayarak değerlendirmeleri ve giderek sorgulama süreçlerini sorgulamalarıdır (Giasson, 1991). Bu sorgulamanın üçüncü düzeyi olmaktadır. Bu aşamada birey hem kendini hem de sorgulama işlem ve sürecinin tamamını gözden geçirerek sorgulamaktadır. Öğrencilerin sorgulama sürecinde aşama aşama ilerlemesi ve bu becerilerini geliştirmesi beklenmektedir.

\subsection{Sorgulamanın Yararları}

Günümüzde eğitim sadece bilgileri alma ve zihne yerleştirme işlemi değildir. Bilgileri anlamadan zihne yerleştirmek mümkün değildir. Bu süreçte sorgulamanın büyük rolü vardır. Sorgulama yapmadan bir bilgiyi derinlemesine anlamak ve öğrenmek mümkün değildir. İnsanlar günlük yaşamda çeşitli bilgileri öğrenmek, anlamak, gelişmelere uyum sağlamak ve mutlu olmak için sorgulama becerilerinden yararlanırlar. Sorgulama işlemi aklı ve bilgileri iyi kullanmayı gerektirmektedir. Bu nedenle insana özgü bir beceri olmaktadır.

Sorgulama öğrencinin zihin yapısında önemli değişme ve gelişmeler yaratmaktadır. Bir başka ifade ile sorgulama öğrencinin önceden oluşturduğu zihinsel şemalarının yapısı ve düzenini değiştirmekte ve bu durum öğrencinin sonraki öğrenmelerini büyük ölçüde kolaylaştırmaktadır. Diğer taraftan sorgulama öğrencinin ön bilgileriyle yeni bilgilerini ilişkilendirmesini sağlayarak anlamlı öğrenmesine yardım etmektedir. Bu nedenle öğrencinin mevcut zihinsel şemalarını iyi düzenlemesi ve yeni zihinsel şemalar oluşturabilmesi için sorgulamaya ağırlık verilmelidir.

Günümüz eğitim anlayışı olan yapılandırıcı yaklaşımda öğrencilerin öğrenmeyi öğrenme becerilerini geliştirme amaçlanmaktadır. Bunun için sorgulama temel ilke olmakta, öğrencileri zihnen aktif kılmak, ön bilgilerini harekete geçirmek ve eleştirel düşünme becerilerini geliştirmek için sorgulamadan yararlanılmaktadır. Öğrencilere okuma sırasında sorular sorma, bir metinde önemli yerlere dikkat çekme, sorularla değerlendirme gibi etkinlikler öğrencilerin öğrenme becerilerini geliştirici olmaktadır. Michel Saint-Onge'e göre öğrenmeyi öğrenme becerilerini geliştirmek için üç ilkeye dikkat edilmelidir.

1. Öğrencilerin kendi sorularıyla sunumlara başlamaları sağlanmalıdır. Bu uygulama merak uyandırmak için en temel ögedir.

2. Derslerde öğrenciler sürekli soru sormaya yöneltilmeli, sordukları sorulara cevap vermeleri için araştırma yapmaları istenmelidir.

3. Öğrenme sorumluluğunu geliştirmek için öğrencilere sürekli soru sorma fırsatı verilmelidir. Bu uygulamalar öğrenmeyi öğrenme becerilerini geliştirici olmaktadır (SaintOnge,1990, s. 11.). 
Sorgulamanın sistemli ve sürekli yapılması da önemli olmakta ve öğrencilere çeşitli yararları bulunmaktadır. Dersteki metinler ve notlar hakkında sürekli sorular sorulması, öğrencilerin bu metin ve notları tekrar okumalarını getirmektedir. Böylece öğrenciler, metinlerde iyi anladıkları ve anlamadıkları yerleri görmektedirler. Metni küçük parçalara ayırma, parça bütün ilişkisini kurma, sorularla bütünleştirme gibi işlemleri daha kolay yapmaktadırlar. Sorgulama öğrenciler arasında işbirliğini de artırmaktadır. Kısaca sorgulayan öğrenciler çeşitli becerilerini geliştirmektedirler. Beyer, sorgulayan öğrencilerin bazı özelliklerini şöyle sıralamaktadır:

- Bir sorunu ya da iddiayı açık biçimde ifade etme,

- Düşünmeden hareket etmeme, düşünme sürecini kontrol etme ve tarafsız düşünme,

- Ön bilgilerini kullanma,

- Sorgulama amacını belirleme, buna uygun yöntem ve teknikleri kullanma,

- Bir düşünceyi oluşturmada azimli olma,

- Bilmediklerini ve bildiklerini ayırt etme,

- Bildiklerinin doğruluğunu belirleme,

- Öne sürülen iddiaları, nedenleri ve kanıtları araştırma,

- Sunulan bilgideki mantıksızlıkları, yanlışıkları ve akıl yürütmeleri tanımlama,

- Olgular ve düşünceler arasındaki farkları ayırt etme,

- Bilginin değerini ya da uygunluğunu değerlendirmek için mantıklı ölçütler belirleme,

- Yeterli kanıt buluncaya kadar yargıdan şüphe etme,

- Temel ve önemli sorular sorarak derinlemesine inceleme,

- Çözümler üretme ve çözümleri değerlendirme (Şahinel, 2002,s:20-21).

Görüldüğü gibi sorgulama öğrencilerde ilgi, yaratıcılık, düşünme gibi süreçleri harekete geçirmekte ve öğrenmeyi öğrenme becerilerini geliştirmektedir. Böylece sorgulama zihinden parmaklara doğru ilerlemekte, öğrencilerin kendilerini sorgulamalarına ve geleceklerine yön vermelerine katkı sağlamaktadır.

\section{EĞiTiM YAKLAŞIMLARINDA SORGULAMA}

Sorgulama anlayışı ve uygulamaları eğitim yaklaşımlarına göre değişmektedir. Aşağıda davranışçı, bilişsel ve yapılandırıcı yaklaşımda sorgulamanın ele alınması ve uygulanması özet olarak verilmektedir.

\subsection{Davranışçı Yaklaşım}

Bu yaklaşımın amacı öğrencinin davranışlarını değiştirmek ve istenilen davranışları öğretmektir. Öğrencilere bir bilgi ya da davranışı öğretmek için defalarca tekrar yapılmakta, olumlu davranışlar pekiştirilerek alışkanlık oluşturmaya çalışılmaktadır. Bunun için öğretim sürecinde çeşitli uyarıcılar kullanma, sürekli tekrar yapma, öğrencinin olumlu davranışlarını pekiştirme, alışkanlık oluşturma üzerinde durulmaktadır. Verilen bir uyarıcıya öğrencinin istenilen tepkiyi göstermesi öğrenme olarak kabul edilmektedir. Öğrenme davranışların değişmesidir. Bu durum bireyin gözlenebilir davranışlarıyla belirlenmektedir. Öğrenciye öğretilecek bilgi ve davranışlar önceden saptanmakta, küçük parçalara ayrılmakta ve çeşitli tekrarlarla öğretilmektedir. Öğrenci değiştirilecek bir varlık olarak ele alınmakta, kişilik ve 
bireysel farklıııklarıyla ilgilenilmemektedir. Bu süreçte eğitim ortamının uygunluğuna da dikkat edilmektedir (Güneş, 2015).

Davranış̧̧ı yaklaşımda zihin bir kara kutuya benzetilmektedir. Bu kutunun içindekilerle yani düşünme, anlama, sorgulama, zihinde yapılandırma gibi süreçlerle ilgilenilmez. Daha çok bu kutuya girdi ve çıktılarla ilgilenilir. Davranış değiştirmeye odaklanıldığından zihinsel becerileri geliştirmeye ağırlık verilmez. Bu yaklaşımın temsilcisi Skinner'e göre "Zihinle ilgilenmek yararsızdır. Çünkü öğrencinin kafasından geçenler görülmez. Bu nedenle eğitim sürecinde öğrencinin bilgileri zihinde yapılandırma durumları dikkate alınmaz ve sorgulamaya yer verilmez (Güneş,2015).

\subsection{Bilişsel Yaklaşım}

Bu yaklaşımda eğitim bilginin zihinde işlenmesi olarak ele alınmakta, öğrenci bilgiyi alan ve işleyen bir bilgisayara benzetilmektedir. Dışarıdan alınan bilgiler kısa süreli bellekte işlenmekte, kodlanmakta ve uzun süreli bellekte depolanmaktadır. Bilgiyi depolama işlemi rastgele ve dağınık değil tam tersine hiyerarşik ve düzenli yapılmaktadır. Bunun için zihinsel şemalar kullanılmaktadır. Zihinsel şemalar bilgileri düzenleme, yerleştirme ve kullanma için gerekli işlemlerin yapıldığı yerlerdir. Öğrencinin zihnindeki şemaların zengin ve gelişmiş olması alınan bilgilerin daha kolay özümlenmesini sağlamaktadır. Bu anlayış sorgulama kavramına da yansımakta ve eğitim sürecinde zihinsel şema geliştiren sorgulamalara ağırlık verilmektedir.

\subsection{Yapılandırıcı Yaklaşım}

Bu yaklaşımda eğitim, bireyin ön bilgileriyle yeni bilgileri birleştirdiği, anlamlandırdığı ve zihinde yapılandırdığı bir süreçtir. Bu yaklaşımda öğrencilerin çeşitli etkinliklerle keşfederek öğrenmeleri, zihinsel süreç ve becerileri geliştirmeleri üzerinde durulmaktadır. Uygulamada gözlem ve inceleme yapma, sorular sorma, merak uyandırma, etkinliklere aktif katılma, işbirlikçi öğrenme gibi çeşitli çalışmalara önem verilmektedir. Böylece öğrencilere "öğrenmeyi öğretme" amaçlanmaktadır (Güneş, 2015). Bir başka ifadeyle bireyin zihinsel işlem ve süreçlerini geliştirerek öğrenme becerileri ile kapasitesi geliştirilmeye çalışılmaktadır. Bu süreçte sadece belirli disiplinlere ait içeriği öğretmeye değil düşünme, anlama, sorgulama, sorun çözme gibi zihinsel becerileri geliştirmeye de ağırlık verilmektedir. Öğrencilere öğrenmeyi öğrenme, girişimci olma, sorumluluk üstlenme, kendi kararlarını verme, kendini yönetme gibi görevler yüklenmektedir. Bu anlayıştan hareketle eğitim sürecinde çeşitli bilgi ve becerileri geliştiren sorgulamalara ağırlık verilmektedir.

\section{SORULAR VE IŞLEVLERI}

Sorgulama işleminin temeli etkili ve nitelikli sorular sormaya dayanmaktadır. Bunlar düşünme ve öğrenme çalışmalarının ilk basamağını oluşturmaktadır. Eğitim alanında sorular düşünme, anlama, öğrenme ve değerlendirme aracı olarak kullanılmaktadır. Soru sorma işlemi genellikle öğretmen tarafından yürütülmektedir. Ayrıca ders kitaplarının da payı büyük olmakta, yazılı soruların çoğunluğu metinlerle birlikte verilmektedir. Bu soruların işlevi ve özellikleri aşağıda verilmektedir.

\subsection{Soruların İşlevleri}

Öğrencilere sorulan soruların çeşitli işlevleri vardır. Pierre Vermersch (2006) bu işlevleri altı başık altında toplamaktadır. Bunlar bilgilenme /öğrenme, sorumluluk yükleme, ölçme, harekete geçirme/güdüleme, beceri/uygulama ve değerlenme gibi sıralanmaktadır (Vermersch, 2006). Bu işlevler aşağıda genel olarak açıklanmaktadır. 
Bilgilenme/Öğrenme işslevi: Eğitim sürecinde sorulan soruların birinci işlevi bilgilenmektir. Yani bireyin sahip olmadığı bir bilgiyi istemesidir. Öğretmen bir konuyu anlatırken ve metni okurken öğrencilere çeşitli sorular sorar. Bilgilenmek için soru sormak konuşarak keşfetmenin eş anlamlısıdır. Bunun için açıklayıcı bilgileri içeren sorulara ağırlık vermek öğrencilerin bilgi düzeyini geliştirici olmaktadır.

Sorumluluk Yükleme işlevi: Soruların ikinci işlevi öğrencilere sorumluluk yükleme, sorumluluklarını hatırlatma, karar verme ve seçmeye yönlendirmektir. Örneğin karar vermeye yönelten bir soru: "Ödevi yapacak mısınız ?" , Sorumluluk almaya yönelten soru: "Söyleyin suçlu mu yoksa suçsuz mu?" "Burada oturmaya kararlı mısın?" gibi sorulardır. Cevap ise "evet" veya "hayır" olmaktadır.

Ölçme işslevi: Soruların önemli bir işlevi de öğrencinin bilgi ve becerilerini ölçmektir. Ölçme soruları öğretmene öğrencilerin öğrenme, anlama, dil ve zihinsel becerilerinin gelişme durumunu değerlendirme aracı olarak hizmet etmektedir. Ayrıca bu sorular öğrencilerin düzeylerini saptama, yeniden anlatılması gereken yerleri belirleme ve daha üst düzeyde düşünme konusunda öğretmene bilgi verici olmaktadır. Metin sonunda verilen sorular genellikle bilgiyi hatırlama, anlama ve algılamayı ölçmeye yönelik olmaktadır. Öğretmenler, bu dengesizliği gidermek için öğrencileri daha üst düzeyde düşünmeye yöneltecek sorulara odaklanmalıdır. Ölçme soruları sadece bilgiye yönelik değil, dil ve zihinsel becerileri geliştirme, düşünce üretme gibi konuları da kapsamalıdır. Örneğin "Kim? Ne Zaman? Nasıl? Nerede? Niçin?" gibi sorular sadece anlamayı değil, öğrenme ve bilgiyi işleme becerilerini de değerlendirici olmaktadır.

Harekete Geçirme/Güdüleme Iş̧levi: Eğitim sürecinde sorulan soruların dördüncü işlevi öğrencileri güdülemek, dikkatlerini yöneltmek, bir konuya dikkat çekmek, düşünmelerini sağlamak, çalışmaya yönlendirmek, işlenen konuyu ve sorunu netleştirmektir. Örneğin "Niye duruyorsunuz? Ne zaman çalışacaksınız?" gibi. Öğrenciler güdülenmekte, sorularla rehberlik edilmekte ve çalışmaların verimli yürütülmesine katkı sağlanmaktadır.

Beceri/Uygulama iş̧levi: Soruların bir başka işlevi de önceden bilinen bir bilgiyi tekrar hatırlatarak uygulamayı kolaylaştırmaktır. Cümleler soru biçiminde veya yarım soru olarak sorulur. Bu tür sorulara genellikle olumlu cevap alınır. Örneğin "Bunun bir suç olduğunu bilmiyor musun? Fatih'in beyaz atını duymadın mı?" Bu tür sorularla öğrencinin konu hakkında bilgilerini gözden geçirmesi, ödev veya uygulamayı doğru yapması beklenmektedir.

Değerlendirme işlevi: Bu soruların işlevi dolaylı olmaktadır. Birey bu sorularla bir garanti, söz, övgü veya güvence almayı amaçlamaktadır. Ayrıca başkalarının görüşlerini almak, başkalarının konuya nasıl baktığını ve değerlendirdiğini belirlemek istemektedir. Örneğin "lyi olmuş mu? Bilimsel düzeyi uygun mu? Yayınlanır mı? "gibi (Vermersch, 2006).

Eğitim sürecinde etkili ve amaca uygun sorular, öğrenmeyi zenginleştirmekte, öğrencilerin performansını artırmaktadır. Bir başka ifadeyle etkili sorular öğrencide merak ve ilgiyi artırmakta, bir öğrenme aracı olarak yeni bilgiler öğrenmeye yönlendirmektedir. Ayrıca öğrencinin derse aktif olarak katılmasını sağlamakta, kavramları sınıflandırma, temel noktaları fark etme ve problem çözme becerilerini geliştirmektedir. Metinle birlikte verilen soruların bir başka işlevi de öğrencinin okuma ve anlama becerilerini geliştirmesi, öğrenciye kendini geliştirme fırsatı vermesidir. Böylece öğrenciler soruların sadece değerlendirme aracı olmadığını, aktif okuyucu olmak için gerekli bir öğrenme biçimi olduğunu anlamaktadırlar.

Sorular sadece öğrencinin değil öğretmenin de sınıf içi çalışmalarını kolaylaştırmaktadır. Öğretmen çeşitli sorularla öğrenmeyi yönlendirmekte, öğrencilerin anlayıp anlamadıklarını kontrol etmekte, öğrenme sürecindeki sorunları keşfetmektedir. Ayrıca 
öğrencilerin etkinliklerini kontrol etmelerine yardım etmekte ve metinleri sorgulama becerilerini geliştirmeleri için sorulardan yararlanma biçimini öğretmektedir. Eğitim sürecinde çeşitli teknikleri öğretmek için de sorulardan yararlanılmaktadır. Bu amaçla öğrenciler sorulara cevap vermeye yönlendirilerek çeşitli teknikleri kullanmaya cesaretlendirilmektedir. Bu süreçte bir soruya cevap verme becerileri de geliştirilmektedir (Giasson, 1997; Fournier, 2005).

\subsection{Soru Türleri}

Sorgulama sürecinde kullanılan sorular sözlü, yazılı, açık uçlu, kısa cevaplı, geliştirme, çıkarım soruları gibi başııklar altında toplanmaktadır. Bunlar aşağıda kısaca açıklanmaktadır.

1. Sözlü Sorular: Öğretmenlerin derslerde sık kullandığı bu sorular genellikle sınıftaki bütün öğrencilere yönelik olmaktadır. Öğretmen bir metni okumadan önce, metni okurken veya metni okuduktan sonra sözlü sorulara başvurmaktadır. Bu sorular öğretim için uygun ancak sınıftaki bütün öğrencileri değerlendirmek için yetersiz kalmaktadır.

2. Yazılı Sorular: Ders kitaplarındaki metinlerin başında ve sonunda öğrencilere yazılı olarak sorulan sorulardır. Bu sorular çeşitli gruplara ayrılmaktadır;

a. Açık Uçlu Sorular: Bu sorular olası çeşitli cevapları içeren sorulardır. Birbirinden farklı ve çeşitli cevapların verilmesine ortam hazırlarlar. Örneğin, "Şiir hakkında ne düşünüyorsun?" gibi. Açıklamalı okuma tekniği ile birlikte yaygın kullanılmaktadır. Açık uçlu sorular öğrencinin karmaşık ve daha üst düzey zihinsel süreçleri kullanmasını gerektirmektedir. Dil ve zihinsel becerileri geliştirmek için uygun sorulardır. Öğrencilerin anlama, düşünme, sorgulama, yazma gibi becerilerini belirlemede, ilgi ve tutumlarını ölçmede bu soru türlerinden yararlanılmaktadır. Ancak uygulamada bazı sınırlııkları da bulunma tadır. Kalabalık grupların ve çok sayıda öğrencinin katıldığı sınavlarda değerlendirme güçlükleri ortaya çıkmaktadır. Bu tür soruların sorulduğu sınavlarda öğrencinin cevaplama işlemi öğretmenin de puanlama işlemi çok zaman almaktadır. Bu nedenle soru sayısı sınırlı olmakta ve bazı konulardan soru sorulabilmektedir.

b. Kısa Cevaplı Sorular: Genellikle kısa ve tek bir cevabı içeren sorulardır. Bu sorulara bir veya birkaç kelime, bir sembol ile cevap verilmektedir. Örneğin, "Bu hikâye hangi mevsimde geçiyor ?" gibi. Öğrenci, sorulara cevap vermek için metinden bilgileri araştırmakta, metni okuyarak yeniden gözden geçirmektedir. Bu sorular bilgi ve hatırlama düzeyinde olduğundan öğrencinin dil ve zihinsel becerilerini geliştirmede yetersiz kalmaktadır. Değerlendirmenin içeriği daha çok bilgiyi anlama ile sınırıdır. Öğrencilere bu tip sorular da öğretilmeli ve soru tipine uygun teknikleri kullanması sağlanmalıdır. Alanda yaygın olarak kullanılan bazı kısa cevaplı sorular aşağıda verilmektedir.

- Çoktan Seçmeli Sorular: Bu soru tipinde liste halinde verilen cevaplardan uygun olanların seçilmesi istenmektedir. Bu sorular, bir dizi seçenekten oluşan testler halinde verilmektedir. Öğrenci testlerden doğru cevabı bulmak ve işaretlemek durumundadır.

-Doğru-Yanlış Tipi Sorular: Bu soru tipinde her sorunun doğru ya da yanlış olma durumu belirlenmekte ve buna göre cevap verilmektedir. Bu sorular, cevap verme konusunda öğrencilere kolaylık sağlamaktadır. Ancak öğrencinin cevapları tesadüfen bulması da söz konusudur.

-Eşleştirmeli Sorular: Birbiriyle ilişkili iki grup olarak verilen sorular belli bir ölçüte göre aralarında ilişkilendirilir. Böylece sorular arasında birleştirme ve eşleştirme yapılır.

3. Geliştirme Soruları: Bu soruların amacı metindeki konular arasında bağ kurmak, öğrencileri cesaretlendirmek, dil, zihinsel, duygusal ve sosyal becerileri geliştirmektir. 
Geliştirme soruları anlamı zihinde yapılandırmaya, iletişim kurmaya ve anlama becerilerini geliştirmeye önemli katkılar sağlamaktadır. Örneğin;

- Sen bu durumda olsaydın ne yapardın?

- Bununla neyi kastediyorsun?

- Bu konuda ne düşünüyorsun?

- Neden bunun üzerinde duruyorsun?

- Biraz daha açıklar mısın?

- Bunu nasıl düşündün? Niçin? gibi

4. Çıkarım Soruları: Bir metinde cevabı açıkça verilmeyen ancak bazı bilgilerden hareket edilerek cevap verilen sorulardır. Bu sorular Johnson ve Johnson (1986) tarafından geliştirilmiş ve Jocelyne Giasson tarafından sınıflandırılmıştır (Giasson,1997). Çıkarım yapmaya dayanak oluşturacak bazı soru örnekleri aşağıda verilmektedir.

- Yer: Olay nerede geçmektedir? Kayıttan sonra görevli bavulları odaya taşıdı.

- $\quad$ Kahraman: Eylemi kim yapıyor? Ayşe kürsüye çıktı ve konuşmaya başladı.

- Zaman: Bu olay ne zaman olmaktadır? Çiçekler açtı ve havalar ısınmaya başladı.

- $\quad$ Eylem: Kişi ne yapmaktadır? Mehmet arabadan indi ve okula doğru koştu.

- Araç: Kişi araç ya da alet olarak ne kullanmaktadır? Cemile Hanım bir elinde iğne, bir elinde makas, elbiseye yöneldi.

- Sınıf: Bu ögeler hangi sınıfa aittir? Traktör ve kamyon garajda, otomobil dışarıdadır.

- $\quad$ Neden-sonuç: Bunun nedeni nedir? Çok sayıda ağaç kırılmış ve yere düşmüştü.

- Sorun-çözüm: Bu sorunun çözümü nedir? Mine'nin, dişi ağrıyor, yanağı da şişmişti.

- Duygu-tutum: Hangi duyguyu hissetti? Diplomamı almak için kürsüye çıktığımda babam gözyaşları içinde beni alkışlıyordu (Güneş, 2014).

Çıkarım yapmak için daha farklı sorulardan ve örneklerden yararlanılabilir. Eğitim sürecinde kullanılan sorular sadece bunlarla sınırlı değildir. Burada önemli görülenler verilmiştir.

\subsection{Soru-Cevap iliş̧kisi}

Metinlerde soru cevap ilişkisi büyük önem taşımaktadır. Jocelyne Giasson'a göre metinlerde soru-cevap ilişkisi iki şekilde ele alınmaktadır. Birincisi, cevabı metin içinde verilen sorular, ikincisi ise cevabı metinde olmayan ancak çıkarımla bulunan sorulardır. Bunlar cevabı metinde ve zihinde olan sorular diye iki grupta toplanmaktadır.

Cevabı Metinde Bulunan Sorular: Bu soruların cevabı metinde verilmekte ve öğrenci metni okuyarak ilgili cevaba ulaşmaktadır. Bu sorular iki gruba ayrılmaktadır. Birincisi, cevabı metinde açıkça verilen sorular, ikincisi ise cevabı metinde araştırılarak bulunan sorulardır. Öğrenci bu soruların cevabını kişisel bilgilerine dayanarak ve metinden araştırarak bulmaktadır. Sorunun cevabı bazen bir cümleden bazen de benzer cümlelerden araştırılarak bulunmaktadır.

Cevabı Zihinde Bulunan Sorular: Bunlar cevabı metinde açıkça verilmeyen sorulardır. Öğrenci kendi zihinsel çabalarıyla cevapları bulmaktadır. Bu sorular ikiye ayrılmaktadır. Birincisi, cevabı yazar ve okuyucunun zihninde olan sorular, ikincisi cevabı sadece okuyucunun 
zihninde olan sorulardır. Bu soruların cevapları yazarın söylemek istediği ve sunduğu bilgilerle okuyucunun zihninin etkileşimi sonucu ortaya çıkmaktadır. Yani yazarla okuyucunun zihinsel etkileşimi sonucu sorulara cevap bulunmaktadır. Bu cevaplar okuyucunun zihinsel ve duygusal yapısına doğrudan bağlıdır. Okuyucunun zihinsel ve duygusal yönden gelişmiş olması cevaplarda belirleyici olmaktadır. Ayrıca cevaplar soru tiplerine göre değişmektedir. Özellikle okuyucunun zihninde olan ve görüşlerine yönelik cevaplar çok değişmektedir (Giasson,1997). Öğrencilerin dil, zihinsel ve duygusal becerilerini geliştirmek için bu sorulara daha fazla ağırlık verilmelidir.

\subsection{Soru Sorma Modelleri}

Araştırmalara göre öğretmenler ders sürelerinin önemli bir bölümünü öğrencilere soru sorarak ve soruları değerlendirerek geçirmektedir. Bu durum öğretmenlerin soru sorma ve sorgulama çalışmalarında bazı noktalara dikkat etmelerini gerektirmektedir. Öğretim sürecinde bazı sorular diğerlerine göre daha etkili olmaktadır. Öğretmen derste izlediği amaca göre soruları seçmelidir. Öğretmen öğrencilerin metni anlamalarına yardım etmek ve zihinsel becerilerini geliştirmek istiyorsa, soruları ayrıntılar yerine ana ögeler üzerinde yoğunlaştırmalıdır ( Giasson, 1997). Etkili bir sorgulama için sorulacak sorular;

- Okumaya yöneltici olmalı,

- Anlama sorunlarını belirlemeye ve çözmeye yönelik olmalı,

- Öğrencinin dil ve zihinsel becerilerini geliştirmeye yardım etmeli,

- Öğrencinin metinle etkileşimini artırmalı,

- Kısa ve açık olmalı,

- Olumsuz cümleler içermemeli,

- Genel olarak, “ Kim?, Ne?, Neden?, Niçin?, Nasıl? Nerede?” ile başlamalıdır.

Eğitim sürecinde soru sorma zamanı da önemli olmaktadır. Bu konuda üç farklı model uygulanmaktadır. Bunlar bir metni okuma öncesi, okuma süreci ve okuma sonrası olarak sıralanmaktadır.

Okuma Öncesi Sorular: Bunlar metni okumadan önce öğrencinin dikkatini çekme ve ön bilgilerini harekete geçirme sorularıdır. Bunlar öğrencilerde ilgi ve merak uyandırmalı ve cevabı zihinde olan sorular olmalıdır. Bu amaçla metnin başlığından ve görsellerinden hareketle tahmin etme soruları, ön bilgilerini harekete geçirme soruları sorulabilir. Bu uygulama öğrencileri güdülemekte, dikkati metne yönlendirmekte ve seçmeli okuma becerilerini geliştirici olmaktadır.

Okuma Sırası Sorular: Metni okurken soru sorma modelinde metne yoğunlaşma ve derinlemesine inceleme becerilerine ağırlık verilmektedir. Bu aşamada sorulan sorular, cevabı metinde olan sorular olmalı, öğrencilerin metni anlama ve becerilerini değerlendirme amacını taşımalıdır. Ayrıca sorular öğrencilerin okuma tekniklerini seçme, en uygun teknik olup olmadığını izleme ve uygulama durumlarını da belirlemeye yönelik olmalıdır.

Okuma Sonrası Sorular: Bu modelde okunan metindeki bilgileri zihinde tutma ve anlama becerilerini geliştirmeye ağırlık verilmektedir. Bu aşamada sorulacak sorular cevabı zihinde olan sorular olmalı, önce okuyucunun zihnindeki cevaplara yönelmeli ardından metin ve yazar hakkındaki görüşler alınmalıdır. Sorular, çıkarım ve yorum yapmaya yönelik olmalıdır. Çıkarımlar, önce sözlü ardından yazılı olarak uygulanmalı, özetleme, paragraf yapma, bir bölüm veya paragraf üzerinde çalışma gibi (Bentolila, Chevalier, Falcoz-Vigne,1991). Her üç aşamada 
sorulan sorular metni okumaya özendirmeli, metnin yatay ve derin yapısını keşfetmeye yönelik olmalıdır (Giasson, 1997).

Görüldüğü gibi sorgulamada kullanılan soruların büyük önemi vardır. Sorular hem düşünme hem öğrenme ve öğretme hem de değerlendirme amaçlı kullanılmaktadır. Kullanılan sorular sözlü, yazılı, açık uçlu, kısa cevaplı, geliştirme, çıkarım soruları vb. çeşitli türlerde olmaktadır. Sorularda soru cevap ilişkisi de büyük önem taşımakta ve cevabı zihinde olan sorulara daha fazla önem verilmektedir. Bu süreçte soru sorma zamanına da dikkat edilmektedir. Bu konuda okuma öncesi, okuma süreci ve okuma sonrası olmak üzere üç farklı model uygulanmaktadır. Böylece öğrencilerin düşünmeleri, etkili ve verimli öğrenmeleri için gerekli çalışmalar yapılmaktadır (Güneş,2012).

\section{SINIF UYGULAMALARI}

Öğretmen sınıfta sorgulama sürecine başlamadan önce bu tekniği iyi bilmeli, gerekli hazırlıkları yapmalı ve aşamalı olarak uygulamalıdır. Bunun için aşağıdaki hususlara dikkat etmelidir.

\subsection{Sorgulama Tekniğini Uygulama}

Sorgulama tekniğinde öğrencilere çok sayıda ve sürekli sorular sorulmakta ve cevaplandırmaları istenmektedir. Bu süreçte dikkat edilecek bazı ögeler şöyle sıralanmaktadır;

- Sorunun amacl,

- Sorunun niteliği,

- $\quad$ Soru türleri,

- Sorgulama biçimi,

- Öğrencilerin cevaplarını genişletme,

- Öğrencilerin cevaplarını öğretmen tarafından yeniden düzeltilmesi,

- Sorgulama işleminin yöntemi.

Sorgulama öğrencilerin yeni bilgileri iyi anlamaları, kavramları ve daha hızlı öğrenmelerini sağlamaktadır. Bu nedenle öğretmen yeni bilgileri verirken konuyla ilgili iyi sorular hazırlamalı, soruların amacına, niteliğine ve türlerine dikkat etmeli, özenle seçmelidir. Soruların konuları kapsaması, öğrencilerde bilgiye ulaşma isteği oluşturması, işbirliği ve grup çalışmasına teşvik etmesi, problem çözme becerilerini geliştirmesi ilkeleri göz önünde tutulmalıdır. Ardından sorgulama sürecinde öğrencilerin verdikleri cevapları düzelterek, genişleterek öğrencilerin öğrenme durumlarını izlemelidir. Ardından öğrencilerin, kendi kendilerine sorular sormalarını, sorgulama yapmalarını, kendi yaptıkları üzerinde düşünmelerini, kendi bilgilerini değerlendirmelerini sağlamalıdır. Böylece süreci iyi anlamaları, yeni beceriler geliştirmeleri ve yeni bilgiler öğrenmeleri sağlanmalıdır.

Sorgulama sürecinde öğretmen öğrencilerle etkili bir iletişim kurmalıdır. Soru sormaktan hoşlanmayan ancak iyi cevaplar isteyen öğretmen bu süreçte başarılı olamaz. Bu nedenle sınıfta önce sorgulamanın amacı açıklanmalıdır. Sorulan sorulara eleştirel veya iyi cevaplar vermeleri gerektiği söylenmelidir. Bu süreçte öğretmen kapalı uçlu sorulardan kaçınmalıdır. Bu sorular çoğu zaman "evet, hayır" gibi basit cümleleri gerektirir. Bunlar kısa ve sınılı cevapları içerdiğinden düşünme ve sorgulama becerilerini geliştirmeye fazla katkı sağlamaz. Bu tür cevaplar bilgileri zihinde yapılandırmayı getirmez. Bu durumu önlemek için açık uçlu sorular sorulmalıdır. Açık uçlu sorular daha ayrıntılı cevapları ve eleştirel düşünmeyi gerektirir. Bu sorular tartışmaya yön verir ve başka konuları araştırmaya eşlik eder. 
Sorgulamada " kim, ne, nerede, niçin, nasıl, ne zaman, kiminle" gibi kelimelerle başlayan sorulardan da yararlanılmalıdır. Bir sorun durumunda en uygun çözümü bulmak için öğrencilerden sorgulama becerilerini kullanmaları istenmelidir.

\subsection{Karşılaşılan Güçlükler}

Sorgulama sürecinde öğretmen bazı güçlüklerle karşılaşmaktadır. Bunların başında sorgulama becerilerinin henüz gelişmemiş olması gelmektedir. Öğretmen sadece bir derste öğrenilen içerik için değil dersin geneli için öğrencilerin sorgulama becerilerini geliştirmek için çalışmalıdır. Bu süreçte öğretmen için ilk olumsuzluk öğrencilerin öğrendikleri bilgileri yeterince hatırlama, ikincisi de anlama düzeyi olmaktadır. Öğrencilerin öğrendiklerini iyi anlayamamaları ve kısa sürede unutmaları sorgulama sürecini olumsuz etkilemektedir.

İkinci güçlük öğrencilerin soruları ve soru düzeyini ayarlayamaması olmaktadır. Bu süreçte öğretmen öğrencilere farklı düzeylerde soruların nasıl hazırlanacağını öğretmelidir. Bu amaçla Bloom taksonomisinden yararlanabilir, soru düzeylerinin özelliklerini ve farkını gösteren örnekler verebilir. Bilindiği gibi Bloom soru düzeylerini;

1. Bilgi basamağı(Hatırlama),

2. Kavrama basamağı(Anlama),

3. Uygulama basamağı,

4. Analiz basamağı(Çözümleme),

5. Sentez basamağı(Birlestirme-Yapılandırma),

6. Değerlendirme basamağı, olmak üzere altı basamağa ayırmıştır. Öğretmen her düzeye uygun soruları ve bu sorular için gerekli ifadeleri açıklamalıdır.

Üçüncü güçlük öğrencilerin soruların amacını anlayamamasıdır. Öğretmen soruların yararı konusunda öğrencilere açıklayııı bilgiler vermeli, sorgulama yönteminin olumlu etkisini anlatmalıdır. Bu yöntemin anlama ve öğrenme becerilerine getireceği katkıları açıklamalıdır (Langevin, 1990, s:12-13).Sonuç olarak eğitimde sürecinde öğrencilere iyi sorular sorulmalı, sorgulama becerileri geliştirilmeli, sorularla öğrenme ve anlama düzeyleri yükseltilmelidir.

\section{Ülkemizdeki Uygulamalar}

Ülkemizde 2005 yılında yapılandırıcı yaklaşım, çoklu zekâ ve öğrenci merkezli öğrenme gibi çeşitli eğitim yaklaşımları temel alınarak ilköğretim programları uygulamaya konulmuştur. $\mathrm{Bu}$ programlarda sorgulamaya geniş yer verilmiştir. Türkçe Dersi (1-5.Sınıflar) Öğretim Programında sorgulamaya ilişkin çeşitli kazanımlarla birlikte sorgulayıcı okuma, dinleme, konuşma, yazma gibi yöntem ve teknikler, yapılacak çalışmalar ve geliştirilecek beceriler belirlenmiştir.

Türkçe Dersi (1-5.Sınıflar) Öğretim Programına göre sorgulama belirli bir amaca yönelik olmalıdır. Bunun için öğrencinin "neyi ve nasıl sorgulayacağı" konusunda amacını belirlemesi gerekmektedir. Öğrencinin amacını belirlemesi, sorgulama sürecini denetim altına almasını, buna uygun ölçüt, yöntem ve teknikleri belirlemesini; bunun yanında sorulara ve sürece yoğunlaşarak konuya hâkim olmasını getirmektedir.

Yine Programa göre Türkçe öğretiminde, öğrencilerin kendilerinin anlam kurmalarına ve bunları yapılandırmalarına yardımcı olmak esastır. Öğrencinin sunulan bilgiyi olduğu gibi ezberlemesi ya da kabul etmesi yerine, bilgiyi sorgulaması sağlanmalıdır. Örneğin metin işlerken yazarın metinde sunduğu "bilgiler, olaylar ve anlam" sorgulanmalı, öğrencinin ön bilgileriyle karşılaştırımalı ve zihinsel süreçler işletilerek yeni bilgiye ulaşılmalıdır. 
Bunların yanında Türkçe Öğretim Programında sorgulama, öğrencilerin hayat boyu kullanabilecekleri karar verme ve çözüm üretme yeteneklerini geliştirmek için bir yöntem olarak verilmiştir. Bu amaçla öğrencilerin okudukları metinleri ve günlük hayatta karşılaştıkları olayları sorgulamaları, onlara çözüm üretmeleri için çeşitli etkinlikler öngörülmüştür. Öğrencilerin, alıştırma yapmak yerine gerçek yaşamlarında karşılaştıkları sorunları ele alması ve bunları inceleyerek, sorgulayarak çözmesi daha iyi öğrenmeyi getireceği vurgulanmıştır (MEB,2005).

Sonuç olarak gelişmiş ülkelerde olduğu gibi ülkemiz eğitim sistemi ile programlarda sorgulamaya geniş yer verilmiştir. Öğrencilerin sorgulama becerilerinin geliştirilmesi üzerinde önemle durulmuş, öğretmen eğitimi ve ders kitaplarında bu konuya dikkat çekilmiştir. Bu çalışmaların iyi yürütülmesi, ülkemizin geleceğine yön verecek düşünen, anlayan ve sorgulayan öğrencilerin yetiştirilmesi vurgulanmıştır. Dileğimiz bu amaçlara ulaşılması ve eğitim düzeyinin yükselmesidir.

\section{KAYNAKLAR}

Adams, Marilee Changez vos questions, changez votre vie. Paris, Éditions Myoho, p. 38.

Astolfi, Jean-Pierre (2008). Le Questionnement Pédagogique, Perspectives, Économie et Management, $n^{\circ} 128, p .70$

Bellenger, L., Philippe P. (1996). Dictionnaire de la formation et du développement personnel, Paris, ESF, 335 p.; ISBN2-7101-1193-4

Bentolila, A., Chevalier, B. and Falcoz-Vigne, D. (1991). La lecture : apprentissage, évaluation, perfectionnement, Théories \& Pratiques, Nathan.

Fournier, C. (2005). Lecture et littérature au cycle 2, Conférence du 9 novembre 2005 Cddp Boulogne.

Giasson, J. (1997). La lecture. De la théorie à la pratique. Bruxelles : De Boeck.

Giasson J.(2008). La Compréhension en lecture, Bruxelles, De Boeck.

Güneş, F. (1997). Okuma Yazma Öğretimi ve Beyin Teknolojisi. Ankara: Ocak.

Güneş, F. (2012). Testlerden Etkinliklere Türkçe Öğretimi. Dil ve Edebiyat Eğitimi Dergisi, 1(1), 31-42. 36

Güneş, F.(2014).Türkçe Öğretimi Yaklaşım ve Modeller. Ankara: Pegem.

Güneş, F.(2015). Sınıf Yönetimi Yaklaşım ve Modeller. Ankara: Pegem.

Langevin, L. 1990).Le questionnement comme stratégie d'enseignement et d'apprentissage, Pédagogie collégiale Septembre 1990, Vol. 4 no:01,p.12-13

Maulini, Olivier (2005). Questionner pour enseigner et apprendre, Paris, ESF.

MEB. (2005). Illköğretim Türkçe Dersi Öğretim Programı, Ankara: MEB Basımevi.

Michel Saint-Onge,(1990) Suffit-il de permettre aux élèves de s'exprimer pour qu'ils le fassent?, Pédagogie collégiale, Vol. 3,No:03, Février 1990, p. 11.)

OCDE(2005). La définition et la sélection des compétences clés, Résumé, Mep_int_French.

Ontario.(2011). L'art de questionner de façon efficace, La Série d'apprentissage professionnel, la Division du rendement des élèves pour soutenir le leadership et l'efficacité de l'enseignement dans les écoles de l'Ontario. Édition Spéciale du Secrétariat,2011, Nº 21

Şahinel, S. (2002). Eleştirel Düşünme. Ankara: Pegem. 
Vermersch, P. (2006). Les fonctions des questions, Expliciter le journal de l'association GREX Groupe de recherche sur l'explicitation $n^{\circ} 65$ juin 2006, CNRS.

Rieunier, A. (2000). Préparer un cours. Tome 1 : Applications pratiques. Tome 2 : Les stratégies pédagogiques efficaces. Paris: ESF.

Viola, Sylvie (2000). L'autoquestionnement en lecture., Sainte-Foy (Québec),Québec Français; numéro 118.

Wragg, E.-C. \& Brown, G. (2001). Questioning in the secondary school. Routeledge, Falmer. New York \& London. 


\section{SUMMARY}

Inquiry as a concept have been used for many years until the age of Socrates. The inquiry attains different meanings in different areas. In education, it is used as "thinking, understanding and increasing the learning levels by developing students' language and mental skills with the questions". The inquiry is the operations of investigating the cause and effect relationship in phenomena by a range of questions, analyzing, producing thoughts, organizing thoughts, defensing them, making comparisons and implications, evaluating discussions and problem solving. The inquiry is also the style of knowledge acquisition, explanation and configuration of the relationship between the concepts. The inquiry is sometimes used having the same meaning of the concepts of problem solving, deciding, reasoning, making relationship and creative thinking. However, the inquiry is different from these concepts. In inquiry, the questions are asked initially and then new ideas are produced.

The inquiry is an activity made daily at home, work and family. The children grows by inquiry. They always question what they see around them in order to understand and learn. The operation of questioning is made intensively at some age levels and takes place at all age levels. The inquiry is not inborn skill. An effective education is needed in order to develop this skill. However, most people do not know how to make inquiry because of not taking an education about it. In this respect, the inquiry takes a wide place in education and functions as an important factor of personal development in developed countries. The students learn the inquiry techniques by various activities.

The inquiry causes important changes and developments in the individuals' mental structures. This case affects and develops other talents in addition to the skills of language, mental and social because the individuals transfer the knowledge and skills attained by inquiry to their real lives and apply them and develop their skills at every area. In this respect, the education of inquiry is started at the primary school grade level as the levels of attaining learning skills and becoming permanent and then extended gradually based on grade levels and areas. Appropriate environments in which the students develop inquiry skills and have fun to learn are designed. At this process, the inquiry proceeds from outside to inside and environment to self and they question themselves.

The inquiry is power at education. The questions asked to the students should be prepared and selected in order to reach this power. Qualified questions are important at students' education, change and development. The questions about especially thinking, understanding and learning develop the students' mental structure and direct productivity and creativity. The people developing and changing humanity and civilization are generally people discovering new products by asking "effective, different and brave" questions. Inquiry directs the students to wisdom and leadership. In this respect, it should be aimed to help the students improve their skills of thinking, understanding, learning and questioning by effective questions, question themselves and develop continuously.

The case that the inquiry is made systematically and continuously is important and provides the students various benefits. Asking questions about the texts and notes taken at the lessons directs the students to read them again. Hence, they can realize the parts that they understand and do not. They can make easily the operations of separating the text into smaller parts, making connection between parts and whole and connecting with the questions. The inquiry encourages the cooperation among the students. Also, the inquiry prompts the students' interest, creativity, thinking processes and improves the skill of learning to learn. Therefore, the inquiry moves from mental to fingers and helps the students question themselves.

The base of inquiry is on effective and qualified questions. The questions which are effective and appropriate for the aims increase interest and curiosity and become media for learning new ideas. Also, it provides active student participation and improves the students' skills of classifying the concepts, realizing the main points and problem solving. Another function of the questions in addition to the text is to improve the students' skills reading and understanding and to provide the opportunity of developing themselves. Hence, the students comprehend that the questions are not only assessment tools but also style of learning needed for being active reader.

The questions used for inquiry are oral, written, open-ended, short answered, developing, implied and so on. The relationship between the question and answer is important in the questions and 
the questions whose answers are on mind are more important. At this process, the time of asking question must be paid attention on. At this point, three different models of before reading, reading process and after reading are applied. Therefore, necessary research can be made for students' thinking, effective and useful learning. To conclude, the inquiry has been taken important place in the education system of our country as in the developed countries. It is emphasized in teacher education and textbooks. It is aimed that these studies have been made well and the students directing the future of our country, thinking, understanding and questioning. 